\title{
PENGGUNAAN YOUTUBE SEBAGAI MEDIA PEMBELAJARAN TEKS NEGOSIASI DALAM MENINGKATKAN MINAT BELAJAR SISWA KELAS X SMK SWASTA DI JAKARTA TIMUR
}

\author{
NENI AMALIYAH \\ SMK Dinamika Pembangunan 1 Jakarta \\ e-mail: like7917@gmail.com
}

\begin{abstract}
ABSTRAK
Pelajaran Bahasa Indonesia berperan terhadap perkembangan sosial, intelektual, dan emosional peserta didik. Dengan adanya pelajaran bahasa Indonesia diharapkan dapat membantu peserta didik untuk membentuk karakter berbahasa sopan, budaya, mengemukakan pendapat dengan baik, dan meningkatkan kemampuan analisis serta imajinatif. Mata pelajaran bahasa ini memiliki problematika terbesar, yaitu kurangnya kreativitas metode dan media ajar sehingga membuat peserta didik jenuh mengikuti proses belajar-mengajar di kelas. Penulis mencoba mengungkapkan perlu adanya pembaharuhan media ajar. Media ajar yang digunakan harus dekat dengan kehidupan sehari-hari peserta didik seperti media sosial khususnya YouTube. Belajar dan ngobrol santai dengan keluarga sering menggunakan sosial media. Era globalisasi dan teknologi sosial media dari kehidupan masyarakat modern. Kebiasaan menggunakan media sosial ini secara tidak langsung dapat menjadikan penggunanya mengakses informasi dan mempelajari informasi yang diaksesnya, sehingga tidak heran jika saat ini perekembangan dan penyebaran bahasa berjalan dengan sangat cepat. Era digital ini menandai bahwa saat ini masyarakat sudah menjadi masyarakat yang modern. Sosial media yang digunakan pada penelitian ini, yaitu YouTube. Selain menggunakan YouTube, penulis juga mengungkapkan adanya kesadaran minat belajar siswa pada saat menggunakan media sosial ini, adakah peningkatannya dalam belajar Bahasa Indonesia, khususnya dalam materi bernegosiasi ini.
\end{abstract}

Kata kunci: Bahasa Indonesia, media pembelajaran, sosial media, minat belajar, teks negosiasi.

\section{ABSTRACT}

Indonesian language lessons play a role in the social, intellectual, and emotional development of students. With Indonesian language lessons, it is hoped that it can help students to form polite language characters, culture, express opinions well, and improve analytical and imaginative skills. This language subject has the biggest problem, namely the lack of creativity in teaching methods and media so that it makes students bored in participating in the teaching and learning process in class. The author tries to reveal the need for a renewal of teaching media. The teaching media used must be close to the daily lives of students such as social media, especially YouTube. Learn and chat casually with family often using social media. The era of globalization and social media technology from the life of modern society. This habit of using social media can indirectly make users access information and learn the information they access, so it is not surprising that currently the development and dissemination of language is running very fast. This digital era marks that today's society has become a modern society. The social media used in this research is YouTube. In addition to using YouTube, the author also reveals that there is an awareness of students' interest in learning when using this social media, is there an improvement in learning Indonesian, especially in this negotiating material.

Keywords: Indonesian language, learning media, social media, interest in learning, negotiating text.

\section{PENDAHULUAN}

Pembelajaran bahasa dalam dunia pendidikan dapat dirasakan manfaatnya terutama dalam penyampaian mata pelajaran bahasa Indonesia. Pembelajaran bahasa yang bertujuan meningkatkan kemampuan berkomunikasi mencakup empat bidang keterampilan bahasa, yaitu 


\section{VOCATIONAL : Jurnal Inovasi Pendidikan Kejuruan Vol. 1 No. 4 Oktober 2021 e-ISSN : 2774-6283 | p-ISSN : 2775-0019}

menyimak, berbicara (keterampilan reseptif lisan dan tulisan), membaca, dan menulis (keterampilan produktif lisan dan tulisan). Kemampuan berbahasa Indonesia secara tertulis merupakan salah satu aspek kemampuan berbahasa yang perlu diajarkan kepada siswa secara serius karena pembelajaran menulis berkaitan dengan proses belajar untuk berpikir secara kreatif. Siswa dalam pembelajaran menulis akan lebih dituntut untuk terus menambah pengetahuannya, baik yang berkaitan dengan tema, isi karangan ataupun teknik penulisan yang baik. Dari empat keterampilan berbahasa itu, menulis merupakan keterampilan berbahasa yang paling kompleks karena keterampilan menulis sangat memerlukan keterampilan berbahasa lainnya agar tulisan yang diwujudkan dapat dipahami. Selain hanya itu, kemampuan ini tidak diperlukan pada saat siswa mengenyam pendidikan, melainkan juga dapat bermanfaat dalam kehidupan mereka ketika sudah hidup bermasyarakat. Berdasarkan hal tersebut, maka tidak heran jika kemampuan menulis sudah diajarkan semenjak siswa mengenyam pendidikan dari bangku SD sampai perguruan tinggi.

Pada hakekatnya menulis merupakan kegiatan menyusun atau mengorganisasikan buah pikiran, ide, atau gagasan dengan menggunakan rangkaian kalimat yang logis dan terpadu dalam bahasa tulis. Menulis merupakan salah satu keterampilan berbahasa yang dibutuhkan untuk meningkatkan kualitas pembelajaran. Menurut (Gie, 2002), menulis memiliki kesamaan makna dengan mengarang yaitu kegiatan seseorang mengungkapkan gagasan atau pemikiran melalui bahasa tulis pada pembaca untuk dapat dipahami dengan tepat sesuai dengan maksud penulis atau pengarang. Seseorang yang menulis, mampu menguasai tata bahasa, struktur, serta ejaan yang benar, karena kefasihan keterampilan menulis seseorang dapat dilihat dari unsurunsur tersebut. Dengan penguasan keterampilan menulis, diharapkan siswa dapat mengungkapkan gagasan dan pemikirannya setelah menjalani proses pembelajaran dalam berbagai jenis tulisan, baik fiksi maupun nonfiksi. Pengungkapan tersebut merupakan peresapan, pemahaman dan tanggapan siswa terhadap berbagai hal yang diperoleh dalam proses pembelajaran.

Menurut Hayon (2007:5), menulis adalah segala kegiatan yang berkaitan dengan perihal menulis. Menulis ada hubungannya dengan orang yang menulis, bahan yang ditulis dan masyarakat sebagai sasaran pembaca. Itulah dunia kepenulisan yang saling berkaitan satu sama lainnya. Unsur-unsur dalam menulis minimal mencapai empat aspek, yaitu (1) aspek gagasan yang akan disampaikan yang berupa topik masalah, (2) aspek tulisan yang berbentuk jenis karangan, sebagai gaya cara menulis karangan narasi, deskripsi, argumentasi, persuasi, atau eksposisi agar pembaca dapat mencerna tulisannya, (3) aspek keterpaduan antarparagraf agar tidak tumpang tindih pembahasannya, dan (4) aspek bahasa memilih diksi yang tepat dan gaya bahasa. Dengan demikian, segala informasi, ilmu pengetahuan, dan berbagai kecakapan yang diperoleh siswa dalam pembelajaran perlu adanya komunikasi atau respon yang baik dalam menuangkan ide atau gagasan, dan dalam kegiatan pembelajaran, tidak hanya sekedar hafalan yang mudah dilupakan oleh siswa sesaat setelah menjalani tes.

Seperti yang kita ketahui permasalahan yang ada di lapangan bahwa guru dituntut kompetensinya dalam mengajar, sehingga guru harus menciptakan suasana belajar yang kondusif, bagaimana agar siswa tertarik untuk mempelajari materi tertentu, dengan metode dan teknik tertentu. Sebagai contoh, seorang siswa yang menyukai pelajaran matematika, tentunya ia hanya mempelajari rumus-rumus tertentu, dan hasilnya tidak perlu diinterpretasi menggunakan kata-kata. Akan tetapi, pada saat belajar Bahasa Indonesia dikelas, ia mengantuk dan tidak konsentrasi, karena kurang berminat. Nah, disinilah peran guru harus dapat memodifikasi teknik mengajarnya, apakah dengan menggunakan media audiovisual, mengadakan quiz, ice breaking, ataupun mengadakan pretest dengan beberapa pertanyaan.

Dilihat dari permasalahan yang ada, dalam pembelajaran bahasa Indonesia, khususnya menulis sebuah teks tentunya guru dapat memiliki ide menyediakan media pembelajaran yang menarik, seperti YouTube untuk menumbuhkan minat belajar siswa. Media dapat berupa video, yang menyajikan film atau animasi yang berkaitan dengan materi. Dalam menguasai media pembelajaran ini, guru tentunya memiliki konsep dalam mengatur jalannya penyusunan sebuah 
teks tulisan. Seperti yang kita ketahui bahwa YouTube adalah media sosial yang digunakan oleh ribuan bahkan ratusan ribu masyarakat Indonesia untuk menyalurkan bakat, minat, kreativitas, dan produktivitas seseorang yang memiliki ketentuan-ketentuan tertentu.

Sejauh ini kita melihat ada permasalahan tertentu dari pembelajaran SMK ini, yaitu siswa kurang paham dengan materi-materi esensial yang berasal dari kurikulum, serta praktiknya dalam pembelajaran dan menggunakan kaidah kebahasaan tertentu sangat kurang. Maka dari itu, kita mencoba untuk berinovasi menggunakan media pembelajaran untuk menumbuhkan minat belajar siswa, menggunakan materi teks negosiasi, yang didalamnya melibatkan kalimat efektif dalam berkomunikasi dengan orang lain, tindak tutur yang baik, dan menerapkan teks yang sudah dibuat kedalam sebuah video yang nantinya akan diunggah ke YouTube. Dalam penggunaan YouTube sebagai media pembelajaran, guru menyajikan materi dari YouTube yang sebelumnya memberikan angket kepada siswa, lalu menganalisisnya agar terlihat hasilnya.

\section{METODE PENELITIAN}

Penelitian ini menggunakan pendekatan kualitatif, yaitu penelitian yang membutuhkan deskripsi hasil, menggunakan kata-kata. Menurut Bogdan dan Taylor (Eri Barlian, 2016) penelitian kualitatif adalah penelitian yang mengahsilkan data deskriptif kata-kata tertulis atau lisan dari orang-orang dan prilaku yang dapat diamati.

Tujuan dari dilakukannya Pendekatan kualitatif, yaitu untuk mengetahui bagaimana menggunakan suatu kejadian yang terjadi pada saat yang dialami.Salah satu alasan menggunakan metode kualtitatif yaitu untuk menemukan dan memahami apa yang tersembunyi di balik kejadian yang terkadang merupakan sesuatu yang sulit dimengerti dan dipahami. Dengan demikian, data kualitatif adalah data yang bersifat deskriptif, keterangan, informasi, bersifat kata-kata bukan angka-angka.

Adapun sumber data dalam penelitian ini adalah video di YouTube hasil tugas pelajaran bahasa Indonesia dan angket yang diisi siswa SMK kelas X. Jenis penelitian yang digunakan adalah kualitatif, yaitu dengan mendeskripsikan data berupa video di YouTube hasil tugas mempraktikkan teks negosiasi sesuai kaidah bahasa Indonesia yang baik dan benar. Penelitian kualitatif ini, bertujuan untuk melihat minat belajar siswa terhadap materi Bahasa Indonesia yang disajikan, yaitu materi negosiasi. Apakah dengan menggunakan youtube, siswa jadi lebih meningkat minat belajarnya, atau tidak. Teknik pengumpulan data dalam penelitian ini adalah siswa menyimak materi Bahasa Indonesia mengenai negosiasi lewat YouTube, lalu membuat teksnya dengan berkelompok, dan mempraktikannya dengan membuat video bernegosiasi lalu di upload di YouTube. Teknik yang dipergunakan untuk mengolah data penelitian dengan cara menyimak, menyeleksi data, menganalisis, dan menelaah data, menyimpulkan hasil.

\section{HASIL DAN PEMBAHASAN}

\section{Hasil}

Untuk melihat seberapa besar minat belajar siswa kelas X dalam pembelajaran Bahasa Indonesia, maka peneliti membuat angket/kuisioner yang terdapat beberapa pertanyaan terkait pembelajaran Bahasa Indonesia.

Berdasarkan angket yang telah disebarkan, terdapat minat yang tinggi terhadap pelajaran Bahasa Indonesia, terutama ketertarikan pada pelajaran Bahasa Indonesia sebesar 80\% Sangat Setuju pada pernyataan-pernyataan dalam angket. Angket ini mengemukakan pernyataan yang positif mengenai minat belajar, namun ada juga pernyataan negatif.

Selain memberikan angket, guru juga memberikan tugas membuat video bernegosiasi, yang kemudian di upload ke YouTube, sebelumnya siswa diberikan materi negosiasi, yang didalamnya terdapat struktur, kaidah kebahasaan, langkah-langkah bernegosiasi dengan tepat, dan tujuan bernegosiasi.

Penggunaan media sosial sebagai media pembelajaran meningkatkan antusias mahasiswa untuk mempelajari dan mengerjakan tugas Bahasa Indonesia. Sosial media yang 
digunakan dalam penelitian, yaitu YouTube. Melalui media sosial YouTube siswa akan mendapatkan bahan ajar dan membuat video yang diunggah ke akun tersebut. Peserta ajar beragam ide membuat semenarik mungkin tugas-tugas yang mereka kerjakan. Melalui media sosial YouTube siswa berusaha keras memberikan yang terbaik karena akan ada penilaian dari yang menyukai (like) atau tidak suka (dislike).

Langkah-langkah penggunaan YouTube sebagai media pembelajaran sebagai berikut :

1. Membuat akun YouTube.

2. Guru memilih video-video yang cocok sebagai bahan pembelajaran untuk diunggah ke YouTube.

3. siswa diminta untuk mengikuti YouTube pembelajaran bahasa Indonesia.

4. Selain menyimak video yang diunggah oleh pengajar peserta didik diminta untuk membuat video secara berkelompok sebagai tugas proyek untuk tambahan nilai.

5. Siswa setelah membuat video dan diunggah ke YouTube diberikan tugas untuk analisis hasil video kelompok lain.

Tabel 1. nilai sebelum menggunakan YouTube

\begin{tabular}{|l|l|l|l|l|}
\hline $\begin{array}{l}\text { Nama } \\
\text { Kelompok }\end{array}$ & \multicolumn{4}{|l|}{ Aspek yang Dinilai } \\
\hline & $\begin{array}{l}\text { Ketepatan bahasa yang } \\
\text { digunakan } \\
(10-30)\end{array}$ & $\begin{array}{l}\text { Kesesuaian materi } \\
\text { dengan video } \\
(20-30)\end{array}$ & $\begin{array}{l}\text { Keefektifan } \\
\text { kalimat } \\
(30-40)\end{array}$ & Jumlah skor \\
\hline Cendrawasih & 15 & 20 & 30 & 65 \\
\hline Merpati & 18 & 20 & 30 & 68 \\
\hline Elang & 15 & 20 & 30 & 65 \\
\hline Gagak & 10 & 25 & 30 & 65 \\
\hline Nuri & 13 & 23 & 30 & 66 \\
\hline Beo & 11 & 20 & 30 & 61 \\
\hline
\end{tabular}

Rata-rata skor $=65$

Persentase $=65 \%$

Dapat dirumuskan dengan grafik :

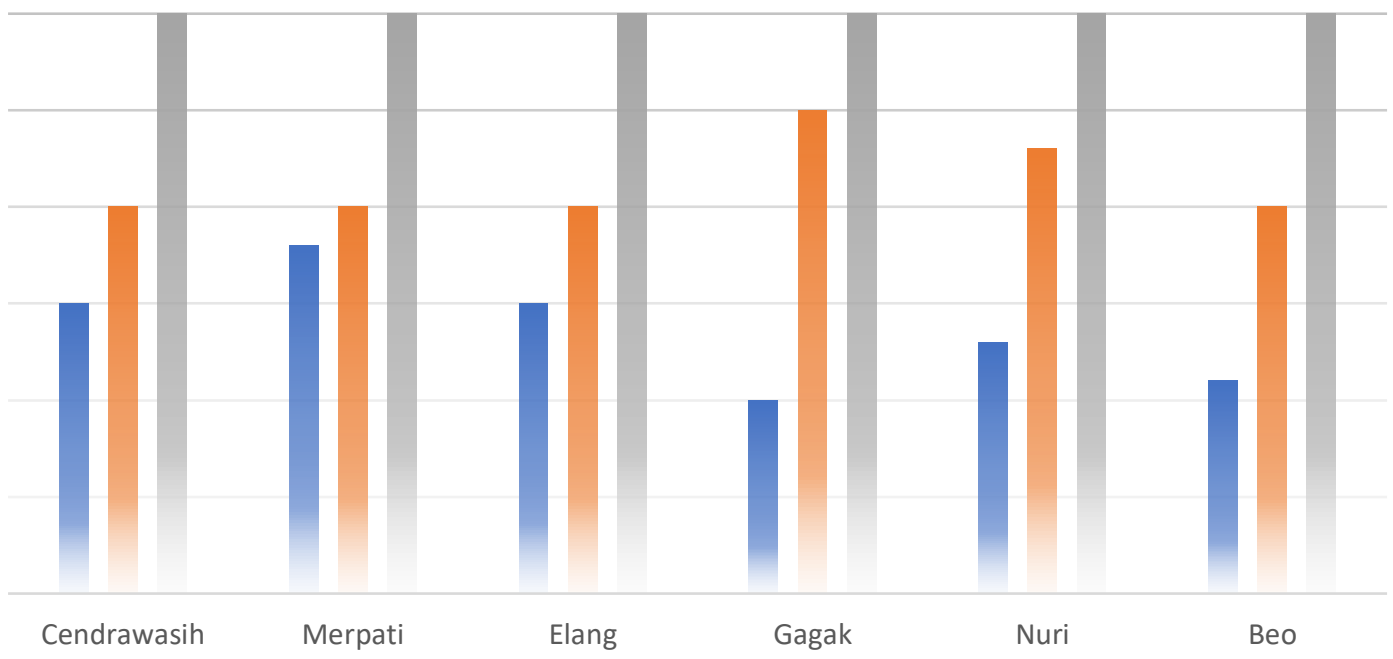

- ketepatan bahasa yang digunakan mesesuaian materi dengan video $\quad$ keefektifan kalimat

Gambar 1. grafik tanpa penggunaan youtube sebagai media pembelajaran 
Tabel 2. nilai sesudah menggunakan YouTube

\begin{tabular}{|l|l|l|l|l|}
\hline $\begin{array}{l}\text { Nama } \\
\text { Kelompok }\end{array}$ & \multicolumn{4}{|l|}{ Aspek yang Dinilai } \\
\hline & $\begin{array}{l}\text { Ketepatan bahasa yang } \\
\text { digunakan } \\
(10-30)\end{array}$ & $\begin{array}{l}\text { Kesesuaian materi } \\
\text { dengan video } \\
(20-30)\end{array}$ & $\begin{array}{l}\text { Keefektifan } \\
\text { kalimat } \\
(30-40)\end{array}$ & $\begin{array}{l}\text { Jumlah } \\
\text { skor }\end{array}$ \\
\hline Mawar & 30 & 25 & 25 & 80 \\
\hline Melati & 28 & 24 & 30 & 82 \\
\hline Kamboja & 30 & 20 & 35 & 85 \\
\hline Bougenville & 30 & 30 & 29 & 89 \\
\hline Teratai & 30 & 30 & 30 & 90 \\
\hline Putri Malu & 30 & 30 & 38 & 98 \\
\hline
\end{tabular}

Rata-rata skor $=81,83$

Persentase $=82 \%$

Dapat dirumuskan dengan grafik sebagai berikut :

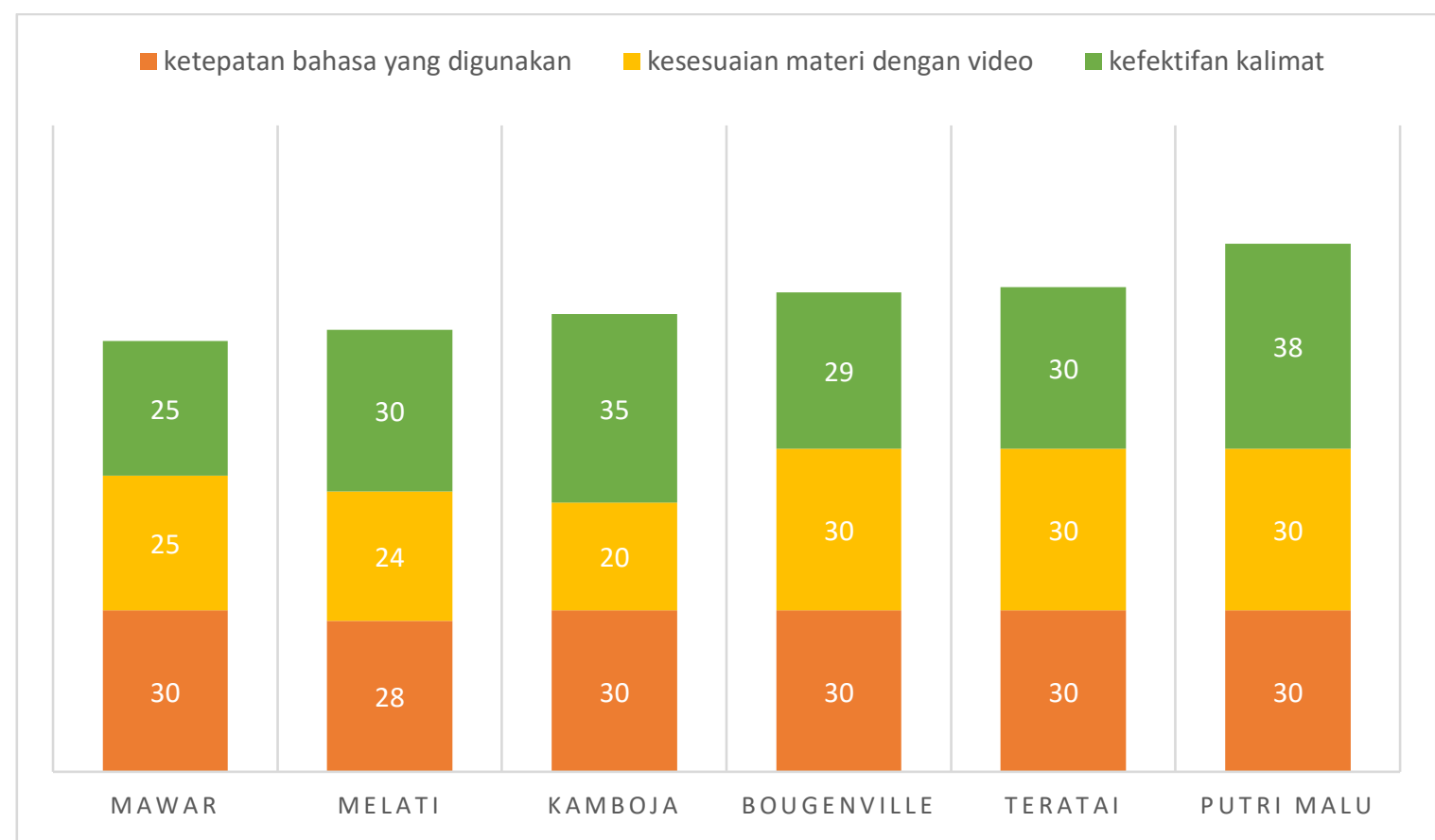

Gambar 2. Grafik Penggunaan YouTube sebagai media pembelajaran

Berdasarkan grafik yang ditayangkan tersebut, terdapat perbandingan, sebelum penggunaan YouTube dan sesudah penggunaan YouTube sebagai media pembelajarannya. Pada grafik pertama, terlihat tidak ada peningkatan, karena siswa kurang memahami materi negosiasi, dan tidak dapat pengenalan materi secara lebih rinci, dan pada grafik kedua, terlihat peningkatan yang signifikan, karena siswa sudah memahami dan membuat pengalamannya secara langsung melalui YouTube, serta dapat berkreasi melalui video bernegosiasi yang sudah dibat.

Aspek penilaian di atas diberikan kepada peserta didik dan mereka diminta untuk lihat YouTube berisi hasil karya teman-temannya yang sudah diunggah. Selain itu, guru dapat melihat aspek penilaian dari komentar-komentar video hasil tugas peserta didik. Peserta didik antusias menganalisis video yang sudah diunggah. Presentasi kehadiran dan pemahaman serta antusias dalam tanya jawab meningkat ketika menggunakan media pembelajaran YouTube. Guru dan siswa menyepakati ada predikat video terbaik sosial media yang mendapatkan tanggapan positif, penayangan terbanyak, dan like terbaik serta tema terbaik. Penilaian dilakukan melalui hasil dari sosial media Youtube, siswa, dan juri (guru Bahasa Indonesia). 
Penilaian dari siswa dan guru dilakukan ketika acara puncak, yaitu pemutaran video bersama. Sedangkan penilaian sosial media dilihat dari hasil unggahan video di Youtube disaksikan secara bersama jumlah like, komentar reviewer terbanyak dan terbaik. Acara penilaian video Youtube selesai dilakukan, dan guru pun melakukan evaluasi secara lisan meminta siswa untuk mengunggakapkan kesan dan pesan saat menggunakan sosial media YouTube sebagai bahan ajar.

Berdasarkan hasil wawancara menggunakan zoom meeting dari 50 siswa yang diambil dari dua kelas, mengungkapkan antusias terhadap pelajaran Bahasa Indonesia karena melalui sosial media mereka dapat menampilkan hasil karya video-video yang dijadikan sebagai tugas serta lebih meningkatkan keakraban antarteman. Sedangkan 3 orang memberikan tanggapan sama seperti sebelumnya tidak ada perubahan. Peserta didik juga menyampaikan bahwa penggunaan sosial media menumbuhkan rasa cinta terhadap bahasa Indonesia dan ingin belajar lebih baik dalam penggunaan bahasa yang baik dan benar. Selama ini peserta didik berpikir jika bahasa Indonesia yang baik dan benar itu sesuai kaidah kebahasaan, akan tetapi ketika dijelaskan dan dipraktikkan ada kesalahan persepsi. Bahasa Indonesia yang baik dan benar, yaitu sesuai situasi penutur dan mitra tutur. Pembuatan video yang diunggah keYouTube membuat peserta didik benar-benar harus belajar menggunakan bahasa Indonesia dan menimbulkan rasa ingin tahu konteks yang benar dalam berbahasa secara lisan. Selain itu, video yang diunggah akan dibuat dengan menarik agar mendapatkan komentar dan like yang banyak. Pemanfaatan YouTube sebagai bahan ajar mempunyai efek positif dalam proses belajarmengajar di dalam dan di luar kelas. Media sosial YouTube tidak lepas dari kehidupan seharihari untuk kalangan remaja. Penggunaan media sosial membuat pandangan positif bahwa bahasa Indonesia bukanlah pelajaran yang membosankan tetapi, sangat mengasyikan bahkan membentuk karakter sosial dan kerjasama antar peserta didik. Oleh karena itu, YouTube dapat menjadi media pembelajaran untuk meningkatkan minat belajar siswa SMK Kelas X dalam pembelajaran bahasa Indonesia.

\section{Pembahasan}

Penggunaan YouTube makin banyak digunakan oleh siswa untuk mencari bahan belajar, bahkan guru pun juga menggunakan YouTube sebagai bahan untuk mencari materi ajar. Youtube adalah media sosial yang menyajikan berbagai pengetahuan, wawasan yang bisa dikembangkan. Banyak orang yang membuat konten dengan tema materi Bahasa Indonesia, untuk menunjang kegiatan pembelajaran. Guru dituntut kreatif, menyesuaikan diri dengan pesatnya perkembangan teknologi, salah satunya media sosial YouTube ini yang terus berkembang dari waktu ke waktu. Seiring dengan berkembangnya media sosial ini, maka dapat dimanfaatkan untuk meningkatkan minat belajar siswa, agar dapat mencapai tujuan pembelajaran. Pemanfaat sosial media memberikan hasil yang signifikan untuk pembelajaran mahasiswa di kampus Mohamed \& Guandasami (2014) serta Abdelazis (2015). Hal tersebut menunjukan bahwa media sosial menjadi alternatif sebagai sarana dalam proses belajar mengajar di era teknologi modern.

Dalam mengembangkan minat belajar maka diperlukan sumber yang jelas mengenai proses perkembangan minat siswa tersebut. Selain itu ciri-ciri minat siswa sangat penting untuk diketahui agar dapat menyusun program pengembangan minat siswa yang efektif, serta mempunyai kebijakan untuk menentukan ke arah mana minat tersebut akan berkembang.

Nasution (2008 : 46) bahwa ketekunan belajar ini bertalian dengan sikap dan minat terhadap pelajaran. Bila suatu pelajaran tidak menarik minat seseorang karena sesuatu hal, maka ia segera menyampingkannya jika menemukan kesulitan. Sebaliknya, jika suatu tugas menarik karena memberikan hasil yang menggembirakan, ia cenderung untuk memberikan waktu yang lebih banyak untuk tugas itu.

Maslow (Sardiman. 2012:47) mengemukakan dorongan dorongan untuk belajar yaitu, adanya kebutuhan fisik, adanya kebutuhan rasa aman (bebas dari kekuatan), adanya kebutuhan 
akan kecintaan dan penerimaan dalam hubungan dengan orang lain, adanya kebutuhan untuk mendapatkan kehormatan dari masyarakat, sesuai dengan sifat seseorang untuk mengemukakan atau mengetengahkan diri.

Dengan kata lain, minat belajar mengindikasikan adanya kecenderungan untuk berusaha aktif meraih manfaat yang diharapkannya. Menurut Slameto (2003:57) minat itu besar pengaruhnya terhadap belajar. Oleh karena itu, minat dapat ditumbuh-kembangkan melalui belajar, sebab melalui belajar seseorang dapat menganalisis informasi-informasi tentang berbagai karakteristik objek kehidupan termasuk informasi tentang pendidikan, jabatan, serta tentang berbagai jenis pekerjaan. Melalui belajar, seseorang akan memperoleh kemampuan dalam berbagai hal, seperti kemampuan berbahasa, berhitung, menulis, menggambar, dan sebagainya itu berguna untuk mendukung kehidupannya. Kemampuan yang dimilikinya tersebut akan mendorong seseorang untuk memiliki minat pada sesuatu. Kecenderungan memiliki kemampuan lebih baik pada satu bidang tertentu akan berdampak pada keberminatan terhadap sesuatu yang berhubungan dengan kemampuannya itu.

Menurut Nasution (2008:36), belajar tuntas merupakan tujuan proses belajar-mengajar secara ideal agar bahan yang dipelajari dikuasai sepenuhnya oleh murid. Salah satunya adalah melalui tes yang diefektifkan sebagai bentuk umpan balik bagi siswa dan guru. Bila bentuk umpan balik ini tepat maka hasil yang dicapai oleh siswa akan menjadi penguatan (reinforcement) untuk terulangnya kembali perilaku yang positif dan berusaha aktif meraih manfaat dari mata pelajaran tersebut. Pengulangan ini terjadi berdasarkan hasil yang diperoleh untuk selanjutnya dikembalikan pada prosesnya yang akan menjadi motivasi yang sangat berarti untuk memicu minatnya mempelajari lebih jauh materi tersebut. Semua ini dilakukan dalam rangka meningkatkan keingin-tahuan dan minat siswa terhadap pokok bahasan atau sub pokok bahasan tertentu yang mengakibatkan hasil belajar meningkat lebih baik. Bila minat telah tumbuh dan terbangun, maka gairah siswa akan bangkit yang menyebabkannya mau mengorbankan waktu, biaya, dan tenaga untuk materi pelajaran yang disukainya itu.

Menurut Bernard (dalam Sardiman. 2012:76) minat timbul tidak secara tibatiba/spontan melainkan timbul dari partisipasi, pengalaman, kebiasaan pada waktu belajar atau bekerja. Jadi jelas soal minat akan selalu berkaitan dengan kebutuhan atau keinginan, oleh karena itu yang penting bagai mana menciptakan kondisi tertentu agar siswa itu selalu butuh dan ingin terus belajar. Dari beberapa pendapat diatas minat belajar dapat diartikan keinginan atau kebutuhan yang timbul dari partisipasi dan pengalaman belajar seseorang yang diciptakan oleh rasa aman dalam proses belajar mengajar sehingga hasil belajar dikuasai sepenuhnya oleh siswa, dan guru harus bisa menciptakan kondisi agar siswa selalu butuh dan ingin terus belajar.

Menurut KBBI, Negosiasi adalah proses tawar-menawar dengan jalan berunding guna mencapai kesepakatan bersama antara satu pihak (kelompok atau organisasi) dan pihak (kelompok atau organisasi) yang lain. Negosiasi adalah penyelesaian sengketa secara damai melalui perundingan antara pihak yang bersengketa.

Menurut Tika Hatikah (2019: 137) Teks yang menjelaskan proses negosiasi. Teks negosiasi berisi kalimat-kalimat kesepakatan mengenai persoalan yang membutuhkan penyelesaian. Teks negosiasi dapat ditemukan dalam bentuk dialog (drama), gabungan antara narasi dan dialog (seperti pada cerpen), atau pada surat penawaran dan permintaan barang.

Teks negosiasi adalah suatu teks yang memuat tentang bentuk interaksi sosial yang berfungsi untuk mencapai kesepakatan di antara pihak-pihak yang mempunyai kepentingan yang berbeda Kemendikbud (2013:134). Dalam negosiasi, pihak-pihak tersebut berusaha menyelesaikan perbedaan itu dengan berdialog. Negosiasi dilakukan karena pihak-pihak yang berkepentingan perlu membuat kesepakatan mengenai persoalan yang menuntut penyelesaian bersama. Teks negosiasi memiliki struktur secara garis besar itu hanya pembuka, isi dan penutup. Sedangkan struktur Teks negosiasi secara terperinci dan lebih detailnya mulai dari penjual - pembeli beserta strukturnya yaitu orientasi, permintaan, pemenuhan, penawaran, persetujuan, pembelian, penutup dan karyawan dengan pengusaha beserta strukturnya yaitu orientasi, pengajuan, penawaran, persetujuan, dan penutup. Negosiasi tidak terlepas dari 
kesepakatan antar dua belah pihak, dan negosiasi yang dilakukan dalam ruang lingkup yang besar, maka akan menghasilkan kesepakatan yang besar pula.

Menurut Sutrisno dan Kusmawan (2007: 8) negosiasi adalah proses komunikasi antara penjual dan calon pembeli baik perorangan maupun kelompok yang di dalamnya terjadi diskusi dan perundingan untuk mencapai kesepakatan tujuan yang saling menguntungkan kedua belah pihak. Negosiasi juga merupakan komunikasi dua arah, yaitu penjual sebagai komunikator dan 13 pembeli sebagai komunikan atau saling bergantian. Negosiasi antara penjual dan pembeli sering kita jumpai disekitar kita, contohnya di pasar tradisional.

Dalam proses negosiasi masing-masing kedua belah pihak harus meletakkan negosiasi di atas segalanya untuk mencapai tujuan dan kesepakatan bersama. Kesepakatan dalam negosiasi ini sebagai sebuah dasar dan jaminan untuk keberhasilan dalam negosiasi (Sutrisno dan Kusmawan, 2007: 9).

Dalam bernegosiasi, terdapat pengajuan, penawaran, dan persetujuan yang sama-sama ditentukan kedua belah pihak yang bernegosasi. Sering Kali kita melakukan negosiasi, tanpa mengetahui struktur, dan kaidah kebahasaannya, yang penting dalam menganalisis percakapanpercakapan yang terlibat dalam negosiasi tersebut.

1. Pengajuan merupakan tahapan awal dalam negosiasi, sebelum memulai percakapan.

2. Penawaran, merupakan inti dalam negosiasi. Dikatakan demikian, karena dalam penawaran, pihak-pihak yang terlibat melakukan negosiasi untuk mencapai kesepakatan Bersama.

3. Persetujuan, biasanya terjadi ketika pihak yang mengajukan pengajuan menyepakati tentang apa yang dinegosiasikan.

Negosiasi tidak hanya berbentuk lisan, tetapi terdapat juga negosiasi tulis. Negosiasi tulis biasanya ditemukan pada surat. Berikut merupakan kelebihan dalam negosiasi.

a) Negosiasi dapat memberikan kemudahan bagi pihak-pihak yang bernegosiasi untuk menentukan pilihannya.

b) Negosiasi dapat memberikan ruang kepada pihak-pihak yang bernegosiasi untuk menentukan kesepakatan bersama sehingga tidak ada pihak yang dirugikan.

\section{KESIMPULAN}

Dapat disimpulkan bahwa penggunaan YouTube dalam pembelajaran Bahasa Indonesia ini, dapat meningkatkan minat belajar siswa, karena siswa dapat mengerjakan tugas berupa video dengan berkelompok, yang dapat dibangun rasa kerjasamanya antar anggota kelompok, selain itu, siswa dapat menilai video negosiasi temannya dengan insrumen penilaian yang sudah disediakan guru. Terdapat persentase yang rendah sebelum menggunakan YouTube sebagai medianya, yaitu sebesar 65\%, sedangkan sesudah menggunakan YouTube sebagai medianya, mengalami peningkatan, yaitu sebesar $82 \%$.

Selain itu, dapat diamati bahwa mata pelajaran Bahasa Indonesia berperan penting untuk perkembangan emosional, sosial, dan intelektual siswa di sekolah. Pembelajaran bahasa Indonesia diharapkan dapat membantu siswa untuk membentuk karakter berbahasa sopan, budaya, mengemukakan pendapat dengan baik, dan meningkatkan kemampuan analisis serta imajinatif.

Pembelajaran bahasa Indonesia memiliki problematika terbesar, yaitu kurangnya kreativitas metode dan media pembelajaran sehingga membuat siswa jenuh mengikuti proses belajar-mengajar di kelas. Pembaruan media sangat penting dilakukan oleh guru. Media pembelajaran yang digunakan harus erat dengan kehidupan sehari-hari siswa seperti media sosial khususnya YouTube. Belajar, ngobrol santai dengan keluarga sering menggunakan media sosial. Saat ini media sosial sudah menjadi bagian dari kehidupan masyarakat modern. Kebiasaan menggunakan media sosial ini secara tidak langsung dapat menjadikan penggunanya mengakses informasi dan mempelajari informasi yang diaksesnya, sehingga tidak heran jika saat ini perekembangan dan penyebaran bahasa berjalan dengan sangat cepat. Era digital ini menandai bahwa saat ini masyarakat sudah menjadi masyarakat yang modern. 


\section{DAFTAR PUSTAKA}

Margono, S. (2003). Metodologi Penelitian Pendidikan, Jakarta: PT Rineka Cipta.

Nasution, S. (1982). Didaktik Azas-Azas Mengajar. Bandung: Jommais.

Nasution, S. (2005). Metode Penelitian Naturalistik Kualitatif. Bandung: Tarsito.

Nasution, S. (2008). Berbagai Pendekatan dalam Proses Belajar Mengajar. Bandung: Bumi Aksara.

Munirah. 2015. Pengembangan Keterampilan Menulis Paragraf. Yogyakarta:Deepublish.

Sardiman, A. M. (2004). Interaksi dan Motivasi Belajar Mengajar. Jakarta : PT Raja Grafindo Persada.

Megaton dan Tarmizi. 2016. Pelayanan Konseling Pada Satuan Pendikan Menengah. Indonesia. Grasindo.

Slameto. (2003). Belajar dan Faktor-Faktor yang Mempengaruhinya. Jakarta: Rineka Cipta.

Muslich, Masnur. 2010. Garis-Garis Besar Tata Bahasa Baku Bahasa Indonesia. Bandung: Reflika Aditama.

Sugiyono. (2016). Metode Penelitian Kuantitatif, Kualitatatif dan R\&D. Bandung: Alfabeta Mulyanis, Tika. 2019. Bahasa Indonesia kelas XI SMK. Bandung : Grafindo Media Pratama. Mulyanis, Tika. 2019. Bahasa Indonesia kelas X SMK. Bandung : Grafindo Media Pratama.

Kemendikbud. 2013. Buku Guru: Bahasa Indonesia Ekspresi Diri dan Akademik untuk Kelas $X$. Jakarta: Kementerian Pendidikan dan Kebudayaan.

Kemendikbud. 2013. Buku Siswa: Bahasa Indonesia Ekspresi Diri dan Akademik untuk Kelas $X$. Jakarta: Kementerian Pendidikan dan kebudayaan

Sutrisno dan Kusmawan Ruswandi. 2007. Modul Melakukan Negosiasi Bisnis dan Manajemen. Sukabumi: Yudhistira. 